\title{
The stem cell marker nestin predicts poor prognosis in human melanoma
}

\author{
FRANCA PIRAS ${ }^{1}$, MARIA TERESA PERRA ${ }^{1}$, DANIELA MURTAS ${ }^{1}$, LUIGI MINERBA $^{2}$, \\ CARLO FLORIS ${ }^{3}$, CRISTINA MAXIA ${ }^{1}$, PAOLO DEMURTAS ${ }^{1}$, JORGE UGALDE ${ }^{1,4}$, \\ DOMENICO RIBATTI ${ }^{5}$ and PAOLA SIRIGU ${ }^{1,4}$
}

\author{
${ }^{1}$ Department of Cytomorphology, University of Cagliari, Cittadella Universitaria, 09042 Monserrato (CA); \\ ${ }^{2}$ Department of Public Health, University of Cagliari, Via Porcell 4, 09124, Cagliari; ${ }^{3}$ Oncologic Hospital \\ 'Businco' Via Jenner, 09100 Cagliari, Italy; ${ }^{4}$ Department of Pathology, Cancer Institute, Solca, Cuenca, Ecuador; \\ ${ }^{5}$ Department of Human Anatomy and Histology, University of Bari Medical School, 70124 Bari, Italy
}

Received August 28, 2009; Accepted September 24, 2009

DOI: 10.3892/or_00000601

\begin{abstract}
The cancer stem cell hypothesis suggests that mutated melanocyte stem cells are present in skin as precursors of melanoma cells. Nestin and CD133 have been described as markers of melanocytic stem cells. The aim of this study was to establish if melanocytic stem cells could have a prognostic significance in melanoma progression. An immunohistochemical study for nestin and CD133 was performed in 130 primary tumors and 32 nodal metastasis biopsy specimens to evaluate possible differences, and to compare the results with survival data and clinicopathological variables. Nestin was expressed in cytoplasm of nonpigmented tumor cells and in endothelial cells, especially at the invading tumor front. Nestin staining in stage I and II (according to the American Joint Committee on Cancer Staging system) melanoma patients significantly predicted poor survival (log-rank test, $\mathrm{P}=0.037$ ), with lower survival rates in cases with nestin positivity in both tumoral and endothelial cells. CD133 staining was not associated with survival. There were no significant differences in nestin or CD133 expression between primary tumors and metastases. These results suggest that nestin expression in both tumoral and endothelial cells may be considered an important early prognostic marker in melanoma.
\end{abstract}

\section{Introduction}

Melanomagenesis and tumor progression are commonly described as 'de-differentiation' processes of transformed,

Correspondence to: Dr Franca Piras, Department of Cytomorphology, University of Cagliari, Cittadella Universitaria, 09042 Monserrato (CA), Italy

E-mail: fpiras@unica.it

Key words: nestin, CD133, melanoma, prognosis, stem cells mature melanocytes, enabling the stepwise metamorphosis from nevus to radial-growth phase (RGP) to vertical-growth phase (VGP) of melanoma and, finally, to metastatic disease. Strikingly, the majority of melanomas emerge in normal skin or unexpected sites along the neural crest migratory route, not in dysplastic nevi (1). An alternative hypothesis has been put forth in light of the cancer stem cell assumption, suggesting that mutated melanocyte stem cells or immature progenitor cells present in skin may act as precursors of melanoma cells (2). Consistent with this hypothesis, recently it has been demonstrated that metastatic melanoma cell lines exhibit morphological, phenotypic and functional features of stem cell population (2-5).

Numerous investigations have provided evidence that the genetic and/or epigenic alterations occurring in the multipotent tissue-specific adult stem cells and/or their early progenies may lead to their malignant transformation into cancer progenitor cells (6). The involvement of cells displaying a stem cell phenotype in cancer formation and progression has been demonstrated in acute myeloid leukaemia, multiple myeloma, head and neck, brain, breast, ovary, prostate, pancreas and colon cancers (7-15).

Markers of melanocytic stem cells have been recently described $(16,17)$, including nestin, an intermediate filament, which is expressed mainly in the cytoplasm of neuroepithelial stem cells $(18,19)$ and in endothelium of growing blood vessels $(20,21)$ but not in differentiated cells in parallel to loss of immunoreactivity to this protein (22). CD133 (human prominin-1/AC133), is another stem cell marker, a transmembrane glycoprotein that is expressed on hematopoietic stem cells, endothelial progenitor cells, and dermalderived stem cells capable of differentiating into neural cells $(23,24)$.

Based on these findings, in the present study we evaluated, in a series of 152 cutaneous melanomas including primary tumors and lymph node metastases, the immunohistochemical expression of nestin and CD133; we correlated their expression with clinico-pathological variables, and we suggest that they may be utilized as potential prognostic markers. 


\section{Materials and methods}

Patients and tissue specimens. Archival tissue blocks from 152 patients, 130 sporadic primary skin melanoma and 32 lymph node metastases, who underwent observation at the Oncologic Hospital 'Businco', Cagliari, Italy, and at the Department of Pathology, Cancer Center of Solca, Cuenca, Ecuador, between November 1995 and April 2008, were selected for this study. The group of patients included 79 women and 73 men, ranging in age from 4 to 100 years (mean age, 62 \pm 17.5 ). The anatomic location of the primary tumors included 21 tumors located in the trunk, 27 head and neck, 22 in upper extremities, and 82 in lower extremities. Complete clinical data, including follow-up until April 2008 were available for 73 patients with stage I and II and for 28 patients with stage IV melanoma, accordingly to the American Joint Committee on Cancer Staging System (AJCC) (25). From 28 patients with stage IV melanoma lymph node metastases were available, whereas their distant metastases were not. The study protocol was approved by the local Research Ethics Committee, according to the World Medical Association Declaration of Helsinki. One condition of the research ethics approval was that only patients that had died or signed an informed consent to the immunohistochemical analysis and to the treatment of their personal data were approved for inclusion in the study.

Each tumor, after surgical resection, was fixed in formalin and embedded in paraffin blocks. Tumoral areas were identified on haematoxylin and eosin-stained sections and on adjacent sections stained for melanoma associated antigens, including S-100 protein, melan A, and HMB-45. Independent histopathological analysis were performed by two pathologists (C.F. and J.U.).

Immunohistochemistry. Serial microtome sections 5- $\mu \mathrm{m}$ thick, were treated immunohistochemically for stem cell markers nestin and CD133, for endothelial cell marker CD31 and melanoma-associated antigens S100, melan A, and HMB45, using the alkaline phosphatase-streptavidin method. Heatinduced antigen retrieval was performed at $95^{\circ} \mathrm{C}$ for $40 \mathrm{~min}$ in $10 \mathrm{mM}$ citrate buffer solution $(\mathrm{pH} 6.0)$, for melan A and $\mathrm{CD} 31$, and by immersion in $0.1 \%$ trypsin solution in PBS at $37^{\circ} \mathrm{C}$ for $10 \mathrm{~min}$, for CD133, S-100 protein and HMB-45 antigen. No antigen retrieval was used for nestin immunostaining. Non-specific binding was blocked with $10 \%$ normal goat serum or normal horse serum for $45 \mathrm{~min}$. Rabbit polyclonal antibodies against nestin (Chemicon International, Temecula, CA, USA; 1:1500 dilution), CD133 (Abcam, Cambridge, UK; 1:1000 dilution), and to bovine S-100 protein (Dakopatts, Glostrup, Denmark; 1:1000 dilution), mouse monoclonal antibodies to human CD31 (clone JC70A; Dakopatts; 1:50 dilution), melan A (clone A103; Dakopatts; 1:100 dilution), and human HMB-45 (clone HMB-45; Dakopatts; 1:100 dilution) were used as primary antisera. Biotinylated anti-rabbit and anti-mouse $\operatorname{IgG}$ were used as secondary antisera (Vector Laboratories, Burlingame, CA; 1:1000 dilution). The sections were further incubated in alkaline phosphatase-streptavidin (Vector Laboratories, Burlingame, CA; 1:1000 dilution) and reacted with Fast Red Substrate System (Dakopatts). Negative controls were established by replacing the primary antibodies with normal serum. Melanoma specimens, which strongly expressed nestin or CD133 were used as positive controls for nestin and CD133 immunostaining.

Since these markers revealed expression in different cells of tumoral mass (18-24), we evaluated tumoral cells and vessels staining separately and in combination. The entire tumor of each case was microscopically examined through x200 magnification fields with a 144-intersection point square reticulum $\left(0.78 \mathrm{~mm}^{2}\right)$ inserted in the eyepiece to count nestin or CD133 immunoreactive cells of whole tumor, and the average of this counts was considered. To confirm that nestin or CD133 positive microvessels were blood vessels, adjacent sections were stained for CD31 and used as control.

Statistical analysis. Data were computed with the SPSS 15.0 statistical software package. The difference of marker expression between primary tumors and metastases, and the correlation of these molecular markers with the clinicopathological variables: sex, age, primary tumor location, tumor Clark level (26), thickness, mitotic index (27), and tumor-infiltrating lymphocytes $(26,28)$ were assessed by Fisher's exact test or Pearson's $\chi^{2}$ test. Overall survival was calculated from the date of histological diagnosis to the date of death caused by the melanoma, or last follow-up, until April 2008. Data on patients who died of other causes were censored at the time of death. The Kaplan-Meier method was used to calculate survival rates. Comparisons were made using the log-rank test. Pairwise comparisons were used for between-group analysis. The $95 \%$ confidence intervals for survival were calculated. All tests used were two-sided. Differences were considered significant at $\mathrm{P}$-values $<0.05$.

\section{Results}

Immunohistochemistry. The true proportion of stem cells in melanoma, whether they are common or rare (29), is still unknown. To clearly define tumors with nestin or CD133 expression, the samples were scored as positive for the expression of nestin or CD133 when $>10 \%$ of tumor cells showed a moderate/strong staining intensity; otherwise, they were scored as negative. The $10 \%$ cut-off was chosen because of the possibility that even a relatively small number of nestin or CD133 positive cancer cells (at least $10 \%$ of the cells) may play a role in melanoma. The samples were scored as positive for the expression of nestin or CD133 in microvessels (capillaries and small venules) when a moderate/ strong staining intensity was found in vessels of peripheral area of tumor or throughout the whole tumor.

Nestin positive cells and vessels were more numerous at the invading tumor front of primary tumors (Fig. 1A) and in the peripheral areas of the multiple small 'nodules' within the tumor mass (Fig. 1B). Nestin expression was observable in cytoplasm of tumoral non-pigmented cells (Fig. 1C) and endothelial cells (Fig. 1D) in most cases. Cases with $>10 \%$ of tumor cells positive for nestin included $64 \%$ of primary tumors and $69 \%$ of lymph node metastases. Forty-eight percent of primary tumors and $50 \%$ of nodal metastases had positive vessels. Among the positive cases, $35 \%$ of primary tumors and $41 \%$ of metastases had both positive cells and 

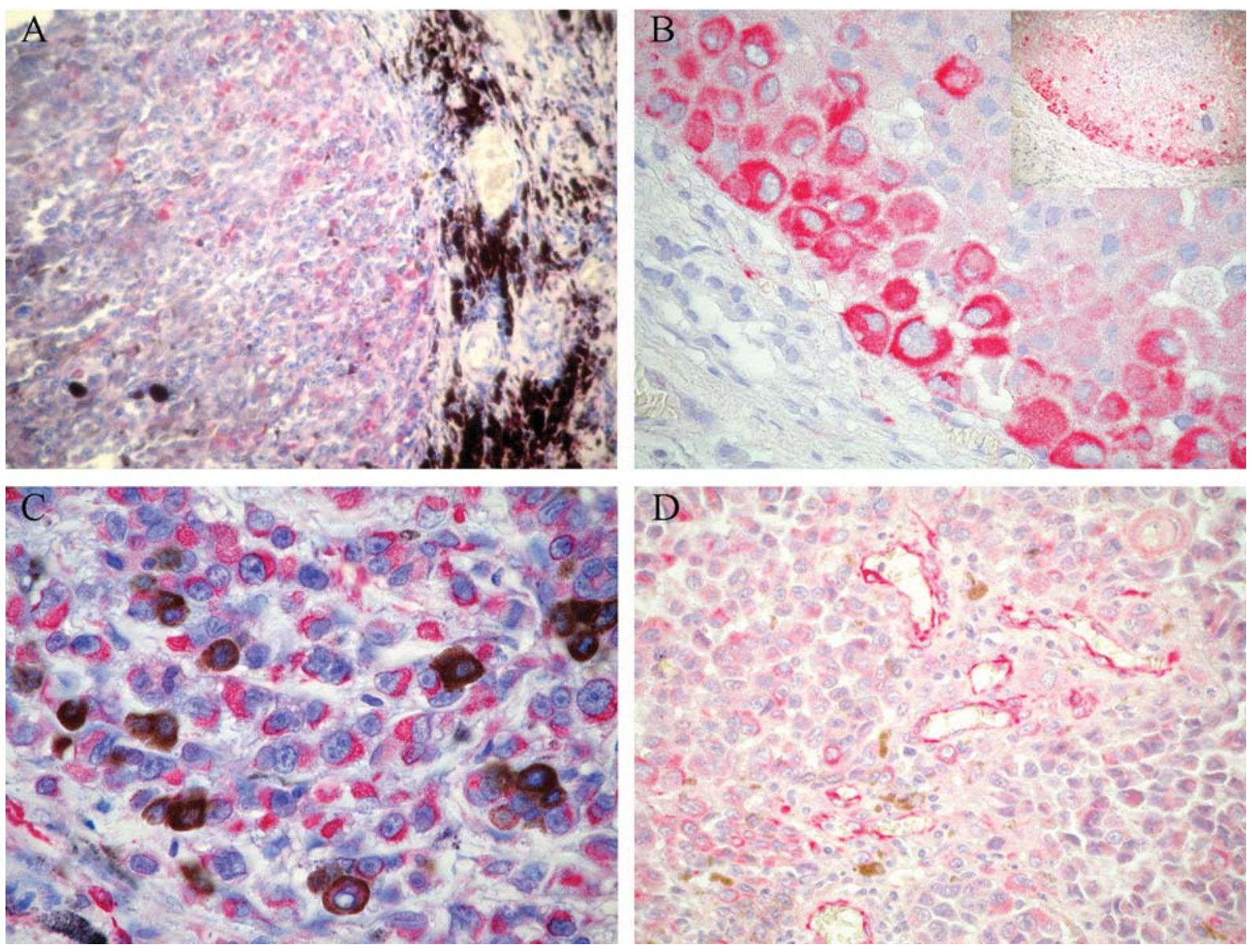

Figure 1. Immunohistochemical staining of nestin in melanoma. Strong nestin expression at the invading tumor front (A). High nestin expression at the peripheral area of the tumor 'nodule' showed at lower power in the upper right inset (B). Presence of cytoplasmic nestin expression in tumoral non-pigmented cells (C). Intense nestin immunoreactivity in endothelial cells (D). Fast Red chromogen. Original magnification, x200 (A); x630 (B and C); x400 (D).

Table I. Nestin and CD133 expression in primary melanomas and lymph nodal metastases.

\begin{tabular}{lcc}
\hline Staining & $\begin{array}{c}\text { Primary tumors } \\
\text { pos/total }(\%)\end{array}$ & $\begin{array}{c}\text { Nodal metastases } \\
\text { pos/total }(\%)\end{array}$ \\
\hline Nestin & & \\
$\quad$ Vessels and cells & $45 / 130(35)$ & $13 / 32(41)$ \\
Only cells & $38 / 130(29)$ & $9 / 32(28)$ \\
Only vessels & $17 / 130(13)$ & $3 / 32(9)$ \\
CD133 & & \\
Vessels and cells & $38 / 106(36)$ & $11 / 32(34)$ \\
Only cells & $16 / 106(15)$ & $6 / 32(19)$ \\
Only vessels & $21 / 106(20)$ & $5 / 32(16)$ \\
\hline
\end{tabular}

vessels. Results concerning nestin expression are shown in Table I.

CD133 staining was detected in cytoplasm of tumoral nonpigmented cells (Fig. 2A) and endothelial cells (Fig. 2B). In most cases, its distribution was similar to that of nestin, with stronger staining at the invading tumor front (Fig. 2C).
Immunohistochemical data are shown in Table I (no paraffin section was available for 24 cases). CD133 immunoreactivity was detectable in $>10 \%$ of positive cells in $51 \%$ of primary tumors and in $53 \%$ of metastases. CD133-positive microvessels were identified in $57 \%$ of primary tumors and in $50 \%$ of metastases. Among the positive cases, $36 \%$ of primary tumors and $34 \%$ of metastases were positive both in tumoral cells and vessels.

Statistical analysis. The Kaplan-Meier analysis showed that the presence of nestin significantly predicted poor survival in patients with stage I and II melanoma (global $\mathrm{P}=0.037$; Fig. 3A; Table II). The pairwise analysis of survival revealed that the best group (the fully negative tumors) in comparison with the worst had a statistically significant better outcome, with a $\mathrm{P}=0.038$. Table III shows the pairwise comparisons used for between-group analysis. There was no significant association between CD133 expression and survival rate of patients with stage I and II melanoma. No clinicopathological factors significantly correlated with overall survival ( $\mathrm{P}>0.05)$. Results of Kaplan-Meier analyses are shown in Table II.

As concerns patients with stage IV melanoma, a high significant correlation between the presence of nestin in tumoral cells $(\mathrm{P}=0.006)$ or in vessels $(\mathrm{P}=0.034)$ of nodal metastases and survival rate was found. Nestin had an higher predictive 

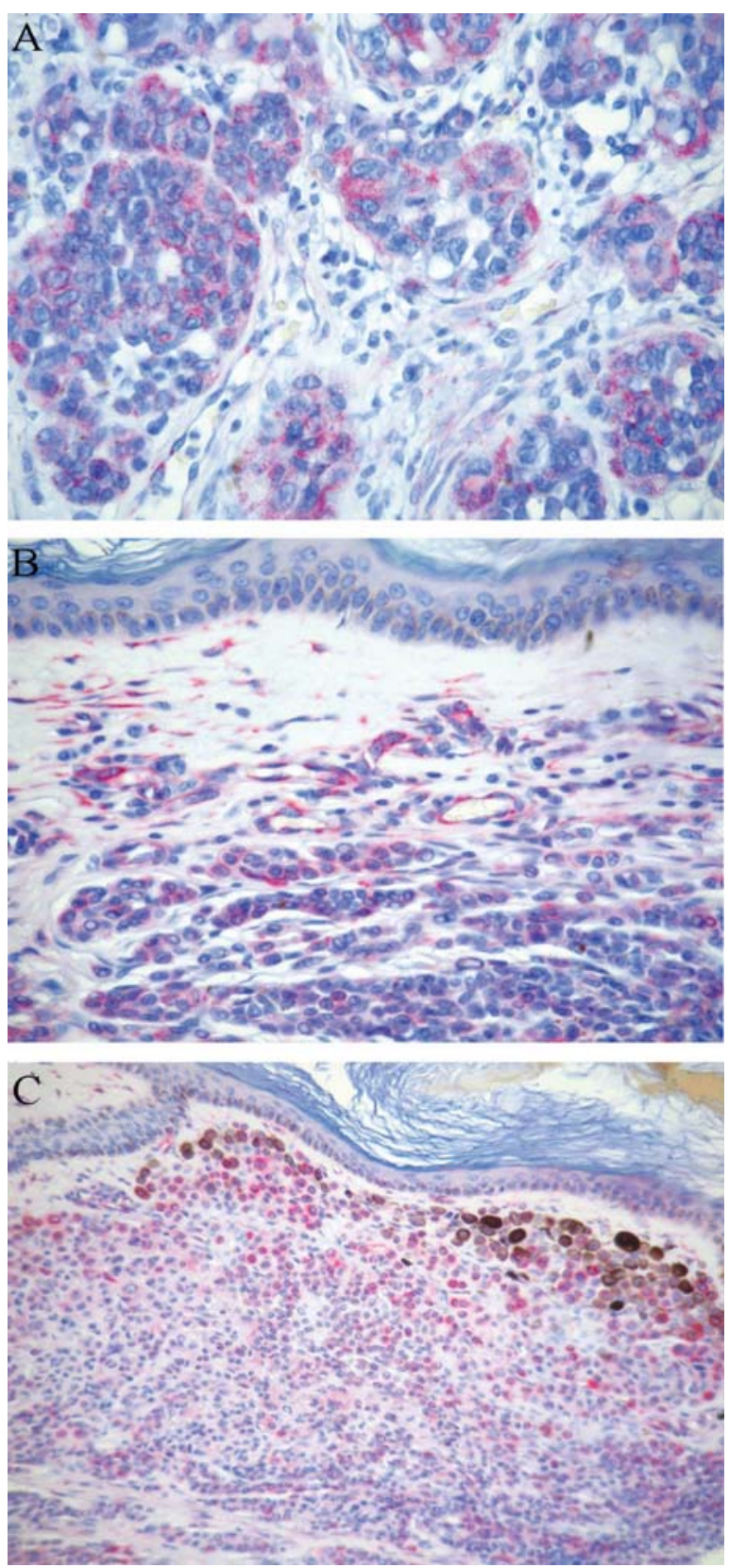

Figure 2. Immunohistochemical staining of CD133 in melanoma. Intense CD133 expression in tumoral non-pigmented cells (A). Presence of CD133 expression in endothelial cells (B). Strong CD133 immunoreactivity at the peripheral area of the tumor 'nodule' (C). Fast Red chromogen. Original magnification, x400 (A and B); x200 (C).

value when its expression in tumoral cells and vessels was studied in combination ( $\mathrm{P}=0.005$; Fig. 3B). $\mathrm{CD} 133$ expression in vessels of nodal metastases was significantly associated with survival rate $(\mathrm{P}=0.008)$, while no significant association was found when only the positivity of tumoral cells or the combination with vessel CD133 expression was evaluated. Results of Kaplan-Meier analyses are shown in Table IV.

No statistically significant difference was present in nestin or CD133 expression between primary tumors and metastases (Fisher's exact test, $\mathrm{P}>0.05$ ) and no significant correlation was found between nestin or CD133 expression with clinicopathological variables (Fisher's exact test, $\mathrm{P}>0.05$ ).
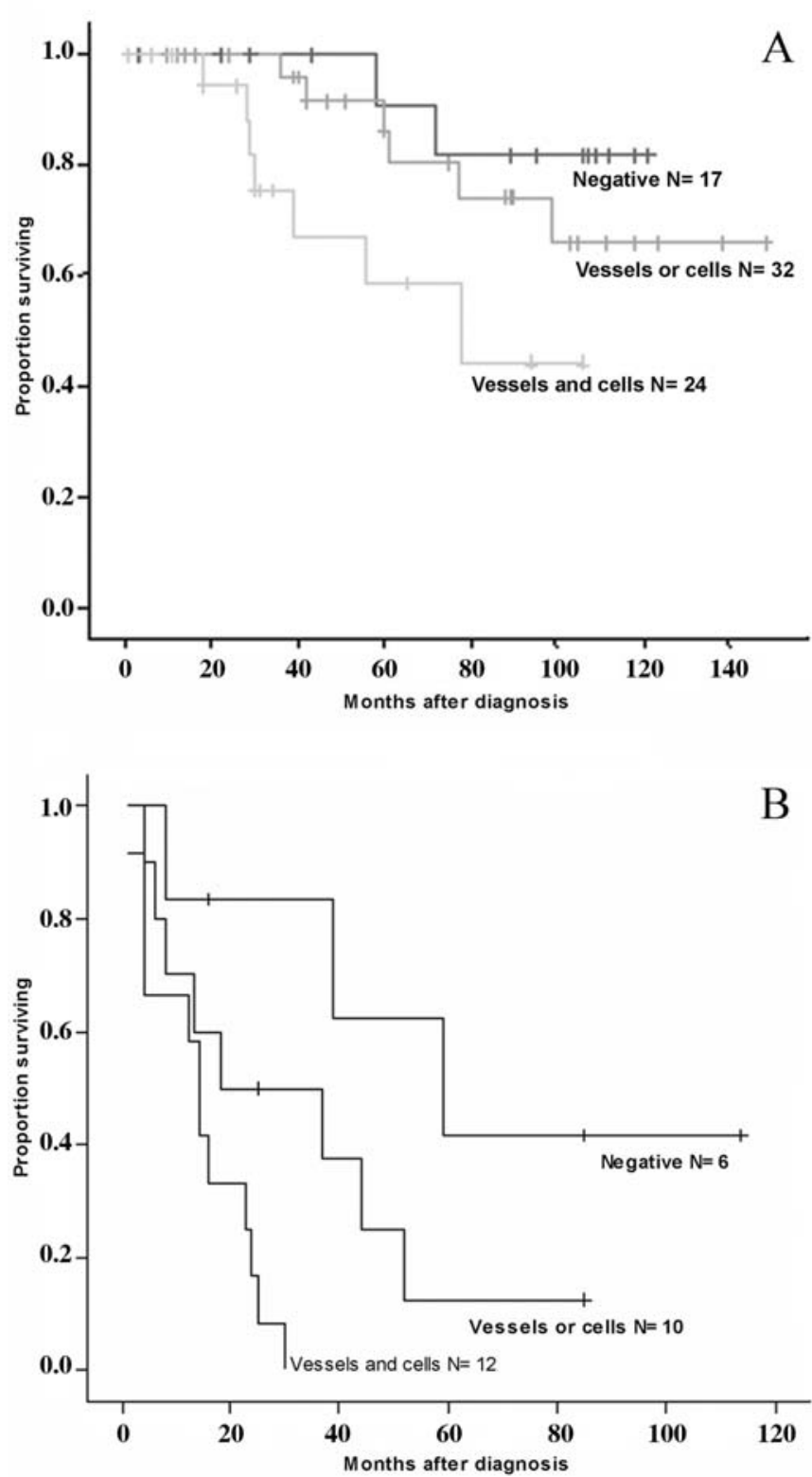

Figure 3. Overall survival of investigated stage I and II melanoma patients with different nestin expression in the primary tumor; global $\mathrm{P}=0.037$ (A). Survival time prediction for stage IV melanoma patients with different nestin expression in lymph node metastases; $\mathrm{P}=0.005$ (B).

\section{Discussion}

The cancer stem cell hypothesis suggests that malignant tumors are formed of cancer stem cells, which have high proliferative potential, and more differentiated cancer cells, with a limited proliferative potential (16).

Since immature melanocytic cells and melanocytic stem cells exist in normal skin $(30,31)$, their role may be analyzed in melanocytic neoplasia. The deregulation of key molecules balancing melanocyte stem cell quiescence, differentiation and self-maintenance, has been linked to melanoma progression after malignant transformation (32-35). Thus, transformed melanocyte stem cells might be involved in the genesis of malignant melanoma and may represent melanoma initiating stem-like cells. 
Table II. Estimated 5- and 10-year survival rates for 73 patients with stage I and II cutaneous melanoma.

\begin{tabular}{|c|c|c|c|c|c|}
\hline Variables & Patients & Events & $\%$ 5-year survival (SE) & \% 10-year survival (SE) & P-value ${ }^{a}$ \\
\hline Age at diagnosis (years) & & & & & 0.631 \\
\hline$<62^{\mathrm{b}}$ & 30 & 6 & $83(7.9)$ & $70(10.9)$ & \\
\hline$\geq 62$ & 43 & 9 & $76(8.6)$ & $60(10.8)$ & \\
\hline Sex & & & & & 0.988 \\
\hline Male & 30 & 6 & $74(10.4)$ & $67.5(11.2)$ & \\
\hline Female & 43 & 9 & $83.1(7)$ & $61(11.1)$ & \\
\hline Anatomic site & & & & & 0.096 \\
\hline Head and neck & 17 & 3 & $81(12.2)$ & $71(14.3)$ & \\
\hline Trunk & 13 & 0 & $100(-)$ & $100(-)$ & \\
\hline Higher extremities & 14 & 2 & $75(15.8)$ & $75(15.8)$ & \\
\hline Lower extremities & 29 & 10 & $72(9.9)$ & $44(12.6)$ & \\
\hline Clark level & & & & & 0.186 \\
\hline II, III & 26 & 4 & $88(7.6)$ & $75(10.8)$ & \\
\hline IV, V & 47 & 11 & $74(8.1)$ & $57(11.2)$ & \\
\hline Tumor thickness & & & & & 0.114 \\
\hline $\mathrm{T} 1$ and $\mathrm{T} 2$ & 27 & 4 & $89(7.2)$ & $77(10.2)$ & \\
\hline $\mathrm{T} 3$ and $\mathrm{T} 4$ & 46 & 11 & $73(8.4)$ & $54(11.8)$ & \\
\hline Mitotic rate & & & & & 0.064 \\
\hline $0 / \mathrm{mm}^{2}$ & 18 & 3 & $86(9.4)$ & $77(11.7)$ & \\
\hline$\leq 6 / \mathrm{mm}^{2}$ & 38 & 5 & $83(7.8)$ & $76(9.7)$ & \\
\hline$>6 / \mathrm{mm}^{2}$ & 17 & 7 & $63(15)$ & $32(14.9)$ & \\
\hline Tumor infiltrating lymphocytes & & & & & 0.650 \\
\hline Absent & 15 & 2 & $60(21.9)$ & $60(21.9)$ & \\
\hline Non-brisk & 21 & 4 & $87(8.6)$ & $67(14.2)$ & \\
\hline Brisk & 37 & 9 & $77(8.2)$ & $62(10.2)$ & \\
\hline Nestin vessels & & & & & 0.102 \\
\hline Negative & 43 & 7 & $86(6.6)$ & $73(8.8)$ & \\
\hline Positive & 30 & 8 & $70(10.4)$ & $49(14.8)$ & \\
\hline Nestin cells & & & & & 0.076 \\
\hline Negative & 23 & 3 & $93(6.4)$ & $78(11.4)$ & \\
\hline Positive & 50 & 12 & $72(8.1)$ & $57(9.9)$ & \\
\hline Combined nestin vessels and cells & & & & & 0.037 \\
\hline Negative & 17 & 2 & $91(8.7)$ & $82(11.6)$ & \\
\hline Only vessels or cells & 32 & 6 & $86(7.5)$ & $66(11.9)$ & \\
\hline Vessels and cells & 24 & 7 & $59(13.4)$ & $44(16.2)$ & \\
\hline CD133 vessels & & & & & 0.589 \\
\hline Negative & 30 & 5 & $82(9.9)$ & $65(13.1)$ & \\
\hline Positive & 26 & 3 & $81(10)$ & $81(10)$ & \\
\hline CD133 cells & & & & & 0.321 \\
\hline Negative & 30 & 3 & $87(8.6)$ & $79(10.9)$ & \\
\hline Positive & 26 & 5 & $75(11)$ & $67(12.6)$ & \\
\hline Combined CD133 vessels and cells & & & & & 0.626 \\
\hline Negative & 21 & 3 & $80(13.4)$ & $67(16.6)$ & \\
\hline Only vessels or cells & 18 & 2 & $92(7.4)$ & $82(11.7)$ & \\
\hline Vessels and cells & 17 & 3 & $70(14.7)$ & $70(14.7)$ & \\
\hline
\end{tabular}

SE, standard error. ${ }^{a}$ Log-rank test; ${ }^{\text {bMean value. }}$ 
Table III. Pairwise comparisons between groups for nestin expression in 73 patients with stage I and II cutaneous melanoma.

\begin{tabular}{|c|c|c|c|c|c|c|}
\hline Nestin expression & Patients & Events & Negative & Only vessels & Only cells & Vessels and cells \\
\hline & & & \multicolumn{4}{|c|}{ P-value } \\
\hline Negative & 17 & 2 & & 0.850 & 0.378 & 0.038 \\
\hline Only vessels & 6 & 1 & 0.850 & & 0.597 & 0.136 \\
\hline Only cells & 26 & 5 & 0.378 & 0.597 & & 0.128 \\
\hline Vessels and cells & 24 & 7 & 0.038 & 0.136 & 0.128 & \\
\hline
\end{tabular}

${ }^{\text {a }}$ Log-rank test.

Table IV. Estimated 5-year survival rates for 28 patients with stage IV cutaneous melanoma.

\begin{tabular}{|c|c|c|c|c|}
\hline Staining & Patients & Events & \% 5-year survival (SE) & P-value ${ }^{a}$ \\
\hline Nestin vessels & & & & 0.034 \\
\hline Negative & 13 & 9 & $26.4(12.9)$ & \\
\hline Positive & 15 & 14 & $0(0)$ & \\
\hline Nestin cells & & & & 0.006 \\
\hline Negative & 9 & 5 & $30.5(17.7)$ & \\
\hline Positive & 19 & 18 & $5.3(5.1)$ & \\
\hline Combined nestin vessels and cells & & & & 0.005 \\
\hline Negative & 6 & 3 & $41.7(22.2)$ & \\
\hline Only vessels or cells & 10 & 8 & $12.5(11.5)$ & \\
\hline Vessels and cells & 12 & 12 & $0(0)$ & \\
\hline CD133 vessels & & & & 0.008 \\
\hline Negative & 13 & 8 & $30.8(14.3)$ & \\
\hline Positive & 15 & 15 & $0(0)$ & \\
\hline CD133 cells & & & & 0.710 \\
\hline Negative & 12 & 9 & $22.2(12.8)$ & \\
\hline Positive & 16 & 14 & $7(6.8)$ & \\
\hline Combined CD133 vessels and cells & & & & 0.190 \\
\hline Negative & 7 & 4 & 38.1 (19.9) & \\
\hline Only vessels or cells & 11 & 9 & $10.9(10.2)$ & \\
\hline Vessels and cells & 10 & 10 & $0(0)$ & \\
\hline
\end{tabular}

SE, standard error. ${ }^{a}$ Log-rank test.

Stem and progenitor cell-associated proteins, such as nestin and CD133, have been described. Nestin has not been detected in neuronal differentiated and mature cells such as Schwann cells and normal melanocytes (22) of adult tissues, whereas its expression re-appears in benign and malignant melanocytic tumors (16,36-39). CD133 has been identified in various solid tumors, including brain, prostate, pancreatic cancer and melanoma (39). These stem-cell markers are more expressed in metastatic melanoma biopsies as compared with primary lesions and/or benign nevi $(16,38)$.
Therefore, the immunohistochemical assessment of nestin expression in differentiating mature and immature cells may be of practical relevance.

In the current study, nestin and CD133 immunostaining was always present in non-pigmented, undifferentiated tumoral cells of all our samples of melanoma, both in primary tumors and in nodal metastases, with a variability in staining intensity and percentage of positive cells. In many cases, nestin and CD133 expression was also observed in endothelial cells of microvessels, especially in the invading tumor front. 
Importantly, in patients with stage I and II melanoma, the simultaneous expression of nestin in a high number of tumoral cells and endothelial cells is associated with a decreased survival time. Moreover, a significant difference was recognizable in 5-year survival among cases positive in both tumoral and endothelial cells $(58.8 \%)$ as compared to all the other cases, in which the positivity was present only in tumoral cells or in vessels $(86.2 \%)$ or in the cases negative to both markers (90.9\%). CD133 expression was not associated with mortality in stage I and II melanoma patients.

Nestin is abundant in embryonic stem-derived progenitor cells that have the potential to develop into neuroectodermal, endodermal and mesodermal lineages (35). Recent reports provided evidence that endothelial precursor cells express nestin, which participates in formation of the cytoskeleton of newly formed endothelial cells and is involved in angiogenesis, even representing a marker of neovascularization $(20,21)$. In this study, we observed nestin positive cells and vessels in the peripheral areas of the tumor, where a less mature population of malignant cells with a higher invasive potential accumulates (38). Moreover, the newly-formed vessels, at the tumor-normal tissue interface, supply the developing tumor with additional oxygen and glucose, and facilitate the metastatic process because the vessel wall of immature capillaries is easily permeable to invading tumor cells (40). For these reasons, the immunostaining profile we described could characterize tumors with an aggressive clinical behaviour and implies that the presence of nestin expression in tumoral cells and vessels can be considered an important factor that leads to a poor prognosis.

In patients with metastatic stage IV melanoma the prognosis remains dismal and it is influenced primarily by the sites and extent of metastatic involvement (41). In our study, decreased survival time of patients with advanced disease was associated with the presence of abundant nestin in tumoral cells and/or vessels, and of CD133 in vessels of nodal metastases. The essential problem confronting clinicians is the ineffective systemic therapies available for patients with regional and distant metastases (41). A characteristic of the normal stem cells is their low immunogenicity $(42,43)$ that, although it represents an advantage for human stem cell therapies, on the other hand it could present a problem for immunotherapy (44). However, recent findings by Quintana et al (29) suggest that a negative correlation may exist in human malignant melanoma, a highly immunogenic cancer, between host immunocompetence and rates of tumor initiation. Moreover, it is well known that normal stem cells are more resistant to cytotoxic agents than mature cells (4547). Therefore, the inability of conventional tumor treatments to achieve long-term cures seems to be related to the fact that cancer stem cells are resistant to many traditional therapeutic approaches.

In conclusion, our findings are consistent with the behavior expected for a tumor based on stem cell biology. Nestin positivity of the vessels and tumoral cells may be considered an important early marker for survival rate in melanoma patients. Further studies should be performed to verify the possibility that nestin can be used in melanoma tumorigenic cell isolation and enrichment approaches with the goal to obtain diagnostic and therapeutic strategies for melanoma.

\section{Acknowledgements}

This study was supported by grants from the Ministero Istruzione Università Ricerca -MIUR-, Ministero Affari Esteri -MAE-, Fondazione Banco di Sardegna. Particular thanks are due to Mrs. Itala Mosso and Mr. Massimo Annis for their expert technical assistance.

\section{References}

1. Schatton T and Frank MH: Cancer stem cells and human malignant melanoma. Pigment Cell Melanoma Res 21: 39-55, 2008 .

2. Grichnik JM, Burch JA, Schulteis RD, et al: Melanoma, a tumor based on a mutant stem cell? J Invest Dermatol 126: 42-153, 2006.

3. Fang D, Nguyen TK, Leishear K, et al: A tumorigenic subpopulation with stem cell properties in melanomas. Cancer Res 65: 9328-9337, 2005.

4. Fang D, Leishear K, Nguyen TK, et al: Defining the conditions for the generation of melanocytes from human embryonic stem cells. Stem Cells 24: 1668-1677, 2006.

5 Dou J, Pan M, Wen P, et al: Isolation and identification of cancer stem-like cells from murine melanoma cell lines. Cell Mol Immunol 4: 467-472, 2007.

6. Mimeault M, Hauke R, Mehta PP and Batra SK: Recent advances in cancer stem/progenitor cell research: therapeutic implications for overcoming resistance to the most aggressive cancers. J Cell Mol Med 11: 981-1011, 2007.

7. Chan WI and Huntly BJ: Leukemia stem cells in acute myeloid leukemia. Semin Oncol 35: 326-335, 2008.

8. Huff CA and Matsui W: Multiple myeloma cancer stem cells. J Clin Oncol 26: 2895-2900, 2008.

9. Prince ME and Ailles LE: Cancer stem cells in head and neck squamous cell cancer. J Clin Oncol 26: 2871-2875, 2008.

10. Das S, Srikanth M and Kessler JA: Cancer stem cells and glioma. Nat Clin Pract Neurol 4: 427-435, 2008.

11. Cariati M: Evaluating the link between stem cells and breast cancer. Expert Rev Anticancer Ther 8: 1313-1322, 2008.

12. Tilly JL and Rueda BR: Stem cell contribution to ovarian development, function, and disease. Endocrinology 149: 43074311, 2008.

13. Taylor RA and Risbridger GP: The path toward identifying prostatic stem cells. Differentiation 76: 671-681, 2008.

14. Lee CJ, Dosch J and Simeone DM: Pancreatic cancer stem cells. J Clin Oncol 26: 2806-2812, 2008.

15. Boman BM and Huang E: Human colon cancer stem cells: a new paradigm in gastrointestinal oncology. J Clin Oncol 26: 2828-2838, 2008.

16. Klein WM, Wu BP, Zhao S, Wu H, Klein-Szanto AJ and Tahan SR: Increased expression of stem cell markers in malignant melanoma. Mod Pathol 20: 102-107, 2007.

17. Mihic-Probst D, Kuster A, Kilgus S, et al: Consistent expression of the stem cell renewal factor BMI-1 in primary and metastatic melanoma. Int J Cancer 121: 1764-1770, 2007.

18. Lendahl U, Zimmerman LB and McKay RD: CNS stem cells express a new class of intermediate filament protein. Cell 60: 585-595, 1990.

19. Dahlstrand J, Zimmerman LB, McKay RD and Lendahl U: Characterization of the human nestin gene reveals a close evolutionary relationship to neurofilaments. J Cell Sci 103: 589-597, 1992.

20. Mokry J, Cízková D, Filip S, Ehrmann J, Osterreicher J, Kolár Z and English D: Nestin expression by newly formed human blood vessels. Stem Cells Dev 13: 658-664, 2004.

21. Mokry J, Cízková D, Ehrmann J, Stanislav F and Kolár Z: Expression of intermediate filament nestin in vascular endothelium. Folia Histochem Cytol 46: 90, 2008.

22. Ehrmann J, Kolár Z and Mokry J: Nestin as a diagnostic and prognostic marker: immunohistochemical analysis of its expression in different tumours. J Clin Pathol 58: 222-223, 2005.

23. Belicchi M, Pisati F, Lopa R, et al: Human skin-derived stem cells migrate throughout forebrain and differentiate into astrocytes after injection into adult mouse brain. J Neurosci Res 77: 475-486, 2004.

24. Shmelkov SV, St Clair R, Lyden D and Rafii S: AC133/CD133/ Prominin-1. Int J Biochem Cell Biol 37: 715-719, 2005. 
25. Balch CM: Cutaneous melanoma. In: AJCC Cancer Staging Manual. Greene FL, Page DL, Fleming ID et al (eds). SpringerVerlag, New York, pp209-217, 2002.

26. Clark WH Jr, Elder DE, Guerry D IV, et al: Model predicting survival in stage I melanoma based on tumor progression. J Natl Cancer Inst 81: 1893-1904, 1989.

27. Schmoeckel C and Braun-Falco O: Prognostic index in malignant melanoma. Arch Dermatol 114: 871-873, 1978.

28. Elder DE, Guerry D IV, VanHorn M, et al: The role of lymph node dissection for clinical stage I malignant melanoma of intermediate thickness (1.51-3.99 mm). Cancer 56: 413-418, 1985.

29. Quintana E, Shackleton M, Sabel MS, Fullen DR, Johnson TM and Morrison SJ: Efficient tumour formation by single human melanoma cells. Nature 456: 593-598, 2008.

30. Yonetani S, Moriyama M, Nishigori C, Osawa M and Nishikawa S: In vitro expansion of immature melanoblasts and their ability to repopulate melanocyte stem cells in the hair follicle. J Invest Dermatol 128: 408-420, 2008.

31. Nishimura EK, Jordan SA, Oshima H, et al: Dominant role of the niche in melanocyte stem cell fate determination. Nature 416: 854-860, 2002.

32. Garraway LA, Widlund HR, Rubin MA, et al: Integrative genomic analyses identify MITF as a lineage survival oncogene amplified in malignant melanoma. Nature 436: 117-122, 2005.

33. Gupta PB, Kuperwasser C, Brunet JP, et al: The melanocyte differentiation program predisposes to metastasis after neoplastic transformation. Nat Genet 37: 1047-1054, 2005.

34. Lang, D, Lu MM, Huang L, et al: Pax3 functions at a nodal point in melanocyte stem cell differentiation. Nature 433: 884-887, 2005.

35. Yang LY, Zheng JK, Liu XM, Hui GZ and Guo LH: Culture of skin-derived precursors and their differentiation into neurons. Chin J Traumatol 7: 91-95, 2004.

36. Amoh Y, Li L, Katsuoka K, Penman S and Hoffman RM: Multipotent nestin-positive, keratin-negative hair-follicle bulge stem cells can form neurons. Proc Natl Acad Sci USA 102: 5530-5534, 2005.
37. Flørenes VA, Holm R, Myklebost O, Lendahl U and Fodstad O: Expression of the neuroectodermal intermediate filament nestin in human melanomas. Cancer Res 54: 354-356, 1994.

38. Brychtova S, Fiuraskova M, Hlobilková A, Brychta $\mathrm{T}$ and Hirnak J: Nestin expression in cutaneous melanomas and melanocytic nevi. J Cutan Pathol 34: 370-375, 2007.

39. Zabierowski SE and Herlyn M: Melanoma stem cells: the dark seed of melanoma. J Clin Oncol 26: 2890-2894, 2008.

40. Sivridis E, Giatromanolaki A and Koukourakis MI: The vascular network of tumours, what is it not for? J Pathol 201: 173-180, 2003.

41. Linette GP, Carlson JA, Slominski A, Mihm MC and Ross JS: Biomarkers in melanoma: stage III and IV disease. Expert Rev Mol Diagn 5: 65-74, 2005.

42. Drukker M and Benvenisty N: The immunogenicity of human embryonic stem derived cells. Trends Biotechnol 22: 136-141, 2004.

43. Drukker M, Katchman H, Katz G, et al: Human embryonic stem cells and their differentiated derivatives are less susceptible to immune rejection than adult cells. Stem Cells 24: 221-229, 2006.

44. Houben R, Wischhusen J, Menaa F, et al: Melanoma stem cells: targets for successful therapy? J Dtsch Dermatol Ges 6: 541-546, 2008.

45. Harrison DE and Lerner CP: Most primitive hematopoietic stem cells are stimulated to cycle rapidly after treatment with 5-fluorouracil. Blood 78: 1237-1240, 1991.

46. Peters R, Leyvraz S and Perey L: Apoptotic regulation in primitive hematopoietic precursors. Blood 92: 2041-2052, 1998.

47. Zhou S, Schuetz JD, Bunting KD, et al: The ABC transporter Bcrp1/ABCG2 is expressed in a wide variety of stem cells and is a molecular determinant of the side-population phenotype. Nat Med 7: 1028-1034, 2001. 